the Upper Cretaceous of Alberta, Canada, are also described in several papers by Mr. Barnum Brown, who discusses chiefly the Trachodontidæ (related to Iguanodon) and the horned dinosaurs or Ceratopsia. Among other observations he makes specially valuable notes on the brain-cavities of these two groups. It appears that just before their extinction the dinosaurs in North America exhibited almost incredible variety and eccentricity.

When the first Tertiary mammals were discovered in North America, too little attention was paid to the geology of the deposits whence they were obtained. The American Museum has, always recognised this deficiency, and the new collection of papers includes some valuable contributions to our knowledge of the lowest Tertiary formations. Of the mammals themselves, Prof. H. F. Osborn describes the skull of Bathyopsis, a supposed ancestor of the Dinocerata, and a skull with other remains of Eomoropus, a new genus ancestral to the anomalous hoofed animals known as Chalicotheriidx. Dr. W. J. Sinclair gives technical descriptions of the rare pieces of jaws of pig-like artiodactyls from the Eocene of North America, and Dr. R. W. Shufeldt discusses many fragmentary remains of birds. Dr. W. D. Matthew also describes the important discovery in the lowest Eocene of New Mexico of the skull of an insectivore related both to the existing Chrysochloris of South Africa and to the extinct Necrolestes of South America, thus proving that the close affinities of these two genera do not imply any former direct connection between the two southern continents in which they occur. All the papers are well illustrated with text-figures and plates, and the American Museum is to be congratulated on the manner as well as the matter of its publications.

A. S. W.

\section{STUDIES OF HYMENOPTERA.}

SOME small hymenopterous parasites of the notorious Hessian fly form the subject of a paper by C. M. Packard in the Journal of Agricultural Research, vi., No. ro. The life-histories of three species belonging to the genera Eupelmus, Merisus, and Micromelus are described, and the figures of eggs, larvæ, and pupæ are especially valuable. The author concludes that never more than a single individual of either of these parasites can mature in a single cecid puparium. Where more than one egg was placed on the same host, one larva onily survived; "the rest were killed by that one or starved to death ... whether the "two or more larvæ were of the same or different species."

It is well known that certain species of the Chalcididæ -small Hymenoptera that are typically parasitic in their habits-lay their eggs in plant tissues on which their larvæ feed, and the genus Megastigmus has been noticed as injurious to fir seeds. J. M. Miller (Journ. Agric. Research, vi., No. 2) is the first to describe the actual operation of egg-laying by these minute flies; the female pierces the scales of the young cones with her long ovipositor and lays the eggs close to the developing seeds. The process is well illustrated by Mr. Miller's photographs.

The literature of the honey-bee is ever increasing. A noteworthy paper on the sense-organs on the mouthparts of the bee is published by Dr. N. E. McIndoo in the Smithsonian Misc. Collections (lxv., No, I4); he gives the results of experiments by feeding bees on various substances, and describes with clear figures the minute structure of the sense-organs under discussion. When "undesirable substances" were added to the bees' food, the insects were found to refuse such "after eating more or less of them," and the author concludes that "the olfactory sense in the honey-bee

NO. 2457 , VOL. 98$]$ is highly developed, and that it serves as an olfactory and gustatory perception combined."

Systematic work on the ants claims the attention of entomologists in distant regions. In the Ann. South African Museum (xiv., part 2), G. Arnold continues his extensive "Monograph of the Formicidæ of South Africa." A. Gallardo publishes a monograph of the Dolichoderinæ as a contribution to "Las Hormigas de la República Argentina," in the Ann. Mus. Nat. de Hist. Nat. de Buenos Aires (xxviii., 1916, pp. I-130), a praiseworthy feature of which is the addition of at least one clear structural figure to the description of each species. The Argentine ant, Iridomyrmex humilis, is discussed at length, the description of its varieties and habits occupying sixteen pages. This insect has in recent years become a serious pest in parts of the United States; colonies have also been introduced into southern Europe, and some time ago these ants gained a temporary footing in a garden near Belfast, whence they invaded the adjacent dwelling-house, with the result of considerable alarm and inconvenience to the inhabitants.

G. H. C.

OBSERVATIONS ON RECENTLY DISCOVERED FOSSIL HUMAN SKULLS. 1 I HE announcements made in NATURE last year (1915, August 5, p. 615; September 9, discovery of fossil human skulls in Australia (Talgai) and South Africa (Boskop) suggest certain observations concerning the problems relating to early mankind. For not only do they add to the number of the distinct types of early humanity with which we are acquainted, but they also force upon us the further consideration of the question of early migrations, of the reality of which the widespread distribution of certain definite types of stone implements already afforded convinoing testimony for all who were willing to accept the plain significance of positive evidence.

There are reasons for believing that when Homo sapiens first became differentiated from other human species many human strains other than those which made their way into western Europe in the Upper Palæolithic (which may be called the Early Neoanthropic, see Nature, August I7, I916, p. 514) age were also budded off from the original parent stock. Some of these diversely specialised strains were the ancestors of the Australians, others of negroes, others again of the Mongolian race, and yet others of the brachycephalic types of humanity, none of which were represented in Europe, excepting possibly the last of the groups mentioned, which began to filter into eastern Europe in Azilian times, but did not become at all common in the West until the closing phases of the Neolithic. 'Some of these various strains wandered far from their area of characterisation; and when brought into contact with other stocks were able to transmit their culture. Thus it is possible to explain how, even in the remote period usually called Palæolithic, identical methods of chipping stone implements in widely separated localities can be regarded as certain evidence of the derivation of the technique from a common source, though the actual makers of the weapons may be of different races. Nor can the source of the inspiration be in doubt even if certain peoples may continue to follow the distinctive methods in the twentieth century.

Further, a particular culture-complex may have been built up of practices and customs derived from varied sources: the particular set of them which becomes intermingled in one area, and the type of culture which develops as the result of the blending of these in-

I Abstract of a paper read before he Manchester Literary and Philo. sophical Society on October 31 by Prof. G Elliot Smith, F.R.S. 
gredients, are peculiar to, and distinctive of, that area. For example, the well-defined culture-complex which is commonly called Neolithic (see Nature, May II, I916) is characteristic of Europe and the immediate neighbourhood; nor, in fact, was it synchronous or of identical composition in different parts of Europe. But when one passes to the East or the South, although all the ingredients out of which the European Neolithic was compounded may be found, there is no phase of culture which can justly be labelled Neolithic in the same sense as the term is applied in Europe.

\section{THE BRITISH ASSOCIATION AT NEWCASTLE.}

\section{SECTION M.}

AGRICULTURE.

\section{Opening Address (Abridged) by E. J. Russell,} D.Sc., President OF the Section.

I AM going to deal to-day with the possibilities and the prospects of increased crop production, which, both in its narrow aspect as a source of national wealth, and in its wider significance as the material basis of rural civilisation, must always remain one of the most important of human activities.

The main obstacles to increased plant-growth lie in the climate and in the soil. Climate apparently. cannot be altered; so we have to adapt ourselves to it by growing crops and varieties suiting the conditions that happen to obtain. But soil can be altered, and it is possible to do a good deal in the way of changing it to suit the crops that are wanted.

On light soil the two great obstacles to be overcome are the lack of water and the poverty in plant nutrients. Both arise from the same cause, the lack of colloidal substances, such as clay and humus, which have the power of absorbing and retaining water and plant nutrients. There are two ways of dealing with the problem; one is to get round it by increasing the depth of soil through which the roots can range, and the other is to remedy the defect by adding the necessary colloidal substances-clay, marl, or organic matter. In practice it is not possible to add sufficient to overcome the defect entirely, and therefore both methods have to be used.

Depth of soil is perhaps the most important single test that can be applied to light sands. If the soil is shallow, and is underlain by solid rock, pebbles, or gravel, the case has hitherto been hopeless, excepting where the climate is persistently moist. I know of no instance of successful treatment in tolerably dry regions; the areas are generally left alone. They form picturesque heaths, some are used as rabbit-warrens or golf courses, some are recommended for afforestation.

If the rock, instead of being solid, is simply a thin layer separating the sand above from a great depth of sand below, then the improvement can be effected by removing it.

Once the light soil is made deeper it can be still further improved. The most permanent improvement is to add clay, or preferably marl; this used to be done in many parts of England, but it now only survives on certain fen or peaty soils.

The usual method of increasing the absorptive power of light sandy soils is to add organic matter, by dressings of farmyard manure, by feeding crops to sheep on the land, or by a method that wants much further investigation, ploughing crops or crop residues straight into the soil. But the organic matter disappears at a very rapid rate, so that the process needs repeating in one form or another every second or third NO. 2457 , VOL. 98 ] year. The addition of organic matter must generally be accompanied by the addition of lime or limestone, otherwise the soil may become "sour"-a remarkable condition, detrimental to plant-growing, but not yet fully understood by chemists, and therefore more easily detected by the vegetation than by analysis. Few light-land farmers use lime or chalk as regularly as they should for the best results.

Further, it is necessary to add all the plant-nutrients, for sand is usually deficient in these, excepting in places calcium phosphate. The common English practice is to import feeding-stuffs to be eaten by sheep on the land, so that the great proportion of the nitrogen, potash, and phosphates thus brought on to the farm shall get straight into the soil. This is not sufficient, however, and artificial manures should be used as well and far more extensively than at present; nitrogen, potash, and phosphates are all wanted.

These additions do not end the matter. Light sandy soils are very prone to weeds, and constant cultivation is necessary to keep them down. Fortunately the cultivation serves another purpose as well; it helps to retain the moisture content of the soil.

Thus the management of a light sandy soil is a constant struggle; it demands constant surface cultivations, frequent additions of fertilisers, of organic matter and lime, and periodical deep ploughings to check any tendency to pan formation. When all this is done these light soils become very productive: they will grow almost any crops, and they can be cultivated easily and at almost, but not quite, any time. One of their chief defects is that cereal crops do not produce so much grain as might be expected; in the words of the practical man, they will not "corn out." This phenomenon requires further investigation.

On the other hand, neglect in any of these directions soon leads to failure.

These are the conditions for the successful management of light soils; how far can they be attained? This is a purely economic question. It is obvious that success is only possible if the gross returns are sufficient to cover the costs. Now, a very great deal of experience has shown that the ordinary farm-cropswheat, barley, swedes, etc.-do not bring in sufficient gross return to encourage good farming. Numerous instances occur on the tracts of light Bagshot sands. Some of the old four-course farms still survivewretched little affairs, the tenants of which are constantly struggling against chronic poverty. Again, considerable areas of light land in Hertfordshire caused their cultivators to go bankrupt in the 'nineties when only these ordinary crops were grown. The old Townshend and Coke method of feeding sheep on the land is satisfactory, but it requires the triple, and not very common, qualifications of capital, good knowledge of sheep, and of crop management. The situation in Hertfordshire was saved by the potato-crop, which, on these farms, brings in a gross return of $25 l$. or more per acre, against a return of $7 l$. from wheat at prewar prices. Of course, the expenditure on potatoes is much greater than on wheat, but that does not matter; the point is that the expenditure has to be incurred in any case if the land is to be kept in good cultivation, and potatoes bring in the necessary return, while wheat does not. Potatoes are the commonest of money-finding crops, but they are not the only one. Greens are in some places very successful, bringing in $\mathrm{I}$ zl. or more gross return. In North Kent various market-garden crops are used. In parts of Norfolk blue peas have answered satisfactorily. Clover-seed is a useful adjunct in places, but it is not sufficiently trustworthy as the chief money-maker.

It is not necessary to take the money-finding crop very often; once in four years may prove sufficient. But the system is capable of considerable intensifica- 